Acta Pædiatr Scand 64: 853-858, 1975

\title{
THE LONG-TERM EFFECTS OF PROTEIN ENERGY \\ MALNUTRITION IN EARLY CHILDHOOD ON BONE AGE, BONE CORTICAL THICKNESS AND HEIGHT
}

PETER J. BRIERS, JAN HOORWEG and J. PAGET STANFIELD

From the Royal Infirmary, Gloucester, Great Britain, the Africa Study Centre, Leyden, Netherlands and the Social Paediatric and Obstetric Research Unit, Glasgow, Scotland

\begin{abstract}
Briers, P. J., Hoorweg, J. C. and Stanfield, J. P. (Royal Infirmary, Gloucester, Great Britain; Africa Study Centre, Netherlands; Social Paediatric and Obstetric Research Unit, Glasgow, Scotland). The long-term effects of protein energy malnutrition in early childhood on bone age, bone cortical thickness and height. Acta Paediatr Scand, 64: 853, 1975. -Three groups of Ugandan children, 18 in each group, and one comparison group of 18 children were examined at 11-17 years of age. The three groups had previously been admitted for treatment of protein energy malnutrition between the ages of 8 to 15,16 to 21 and 22 to 27 months respectively. The comparison group had not been clinically malnourished throughout the period up to 27 months of age. The children came from one tribe and from similar socio-economic background, and were individually matched on age and sex. The bone age was estimated by hand wrist radiography scored for maturity by the Tanner \& Whitehouse method. The metacarpal index, a ratio derived from the medullary width and full diameter of the mid-point of the second metacarpal, was used as a measure of bone cortical thickness. The three malnourished groups are significantly shorter in height than the comparison group, but are not different in bone age and metacarpal index. No differences are observed between the three groups of children who had been admitted for protein energy malnutrition at different ages. The findings are discussed as they relate to the existing literature.
\end{abstract}

KEY WORDS: Protein energy malnutrition, bone age, bone cortical thickness, height

Wotein energy malnutrition of early childhood is known to retard growth in height and bone age but its long-term effects are less certain. Full rehabilitation following a period of malnutrition would require complete "catch up' skeletal growth and maturation such as would achieve the individual's genetically determined trajectory. It has been reported for nutritional disorders other than protein energy malnutrition that this process of "catch up" may take up to 3 or 4 years, depending on the length and severity of the period of nutritional distortion and the adequacy of the rehabilitation $(3,16)$.

In animal studies, however, McCance \&
Widdowson (12) have demonstrated critical periods in growth during which an induced nutritional growth falter gave rise to permanent deficit in size, however adequate the subsequent diet. Furthermore, protein energy malnutrition as it affects the infant and young child in developing countries is far from resembling the closely monitored and controlled process reported in studies such as have been quoted above. The episode of clinical malnutrition may have a fairly acute onset precipitated by infection, but this is very often preceded or followed by periods of more chronic malnutrition interspersed with further infection. Freedom from infection and dietary 
Table 1. Composition of groups

\begin{tabular}{|c|c|c|c|c|}
\hline & \multicolumn{3}{|c|}{$\begin{array}{l}\text { Malnourished children } \\
\text { admitted between: }\end{array}$} & \multirow{2}{*}{$\begin{array}{l}\text { Com- } \\
\text { parison } \\
\text { group }\end{array}$} \\
\hline & $\begin{array}{l}8-15 \\
\text { months }\end{array}$ & $\begin{array}{l}16-21 \\
\text { months }\end{array}$ & $\begin{array}{l}22-27 \\
\text { months }\end{array}$ & \\
\hline Boys & $N=10$ & $N=10$ & $N=10$ & $N=10$ \\
\hline Girls & $N=8$ & $N=8$ & $N=8$ & $N=8$ \\
\hline \multirow{2}{*}{$\begin{array}{l}\text { Present age, } \\
\text { mean (yrs) } \\
\text { Age range (yrs) }\end{array}$} & 14.1 & 14.0 & 13.9 & 13.8 \\
\hline & $12.3-16.8$ & $11.7-16.8$ & $311.7-16.6$ & $11.8-16.7$ \\
\hline
\end{tabular}

intake during the periods of rehabilitation may never be enough for the child to regain his genetic growth trajectory.

Studies of this complex process have produced conflicting results. Krueger (11) and MacWilliams \& Dean (14) suggest that height and bone age are adversely affected for a considerable time after malnutrition in infancy. Keet et al. (10) report no significant differences between former kwashiorkor patients and their siblings in height and bone age after 10 years of follow-up. Garrow \& Pike (7) found no evidence of stunting of growth; instead they found that successfully rehabilitated children tended to outgrow their siblings on their return home.

Bone cortical thickness has been studied by Blanco et al. (4) in a large group of rural Guatemalan children up to 7 years old. They showed that the mean bone cortical measurements of these children were less than those of American children of the same age and concluded that these differences were the result of malnutrition.

In an attempt to clarify the situation, a study was carried out with 11 to 17 year old Ugandan children for whom records of early childhood existed at the British Medical Research Council's Child Nutrition Unit in Kampala, Uganda. These records concerned both children admitted for protein energy malnutrition and children who had maintained a reasonably normal nutritional state in their first three years of life and who had attended a rural child clinic also staffed by the Research Unit. This communication presents the heights of the children and the findings obtained with hand wrist radiographs. The results of other anthropometric measurements and intellectual abilities are to be published.

\section{METHOD}

Three groups of 18 children who had been admitted for protein energy malnutrition between $8-15,16-21$ or 22-27 months of age and who could be traced were selected. The mean age at admission for the three groups was $12.7,191$ and 24.4 months, respectively. A comparison group of 18 children was selected from the children who had attended the rural clinic and who had not suffered from proten energy malnutrition during early childhood. These children had been seen for at least 2 years startung before the age of 12 months and during this period no clinical signs of malnutrition had been recorded and their weigt had not fallen below the tenth percentile of the Boston standard (18). All the children during early childhood had lived in the same or similar rural area.

A randomized block design was used in which the four groups of children were individually matched on sex and age, while only children from one tribe, the Baganda, were included. The groups came from a similar socio-economic background. In each group there were 10 boys and 8 girls, the mean age at present was nearly 14 years with a range from 11.7 to 16.8 years (Table 1). The malnourished children had been admitted between 9 and 15 years previously.

The medical data recorded for the malnourished children at admission was submitted to principal component analysis and varimax rotation of seven medical ind cators recorded during admission: weight (per cent for age), haemoglobin level, serum protein level, weight lost after admission, the degree of oedema, the degree of skin changes and an overall estimate of severity recorded by the attendant doctor. A full discussion of this analysis is to be published. The analysis resulted in two, statistically independent, components of malnutrition. One was 'acute malnutrition', reflected in the severity of metaboly abnormalities, oedema, and skin changes: the other w: 'chronic undernutrition' composed of weight deficit and haemoglobin deficit both reflecting the chronicity of undernutrition underlying the acute episode. For each child both the severity of 'acute malnutrition' and the severity of 'chronic undernutrition' during admission were calculated.

In the current examination, a hand wrist radiograph was obtained for each child, and the bone age assessed by the method of Tanner \& Whitehouse (19). The maturity of each child was expressed as the delay of the child's bone age behind its chronological age.

The metacarpal index, originally described by Barnett \& Nordin (2), was used as an indicator of cortical thickness. The overall diameter at right angles to the long axis of the mid point of the second metacarpal was measured by dividers, and a Vernier rule scale, utilising an ElemaSchönander binocular magnifier. The medullary width at the same point was measured and from these figures the metacarpal index was calculated. 
Table 2. Means of bone age delay, metacarpal index and height for three malnourished groups and comparison group

Malnourished children admitted between

$8-15 \quad 16-21 \quad 22-27$ months months months group

Lag in bone age, mean (yrs)

Metacarpal index

Height (\% for age)
0.63

46.70

92.10
0.77

47.80

91.80
0.71

40.10 cantly different $\left(F=2.40 ; F=0.0^{\prime}\right)$ although the malnourished children show a relative delay in bone age of half a year.

\section{Children admitted early (8-15 months) vs Children admitted later (16-21 and 22-27 months)}

Analysis of variance shows that no significant differences result from the age at which the malnourished children were admitted to the clinic either on bone age delay, metacarpal index or height.

The hand wrist films were examined in random order by me observer who was not aware of the group from which (5) derived. The bone age and metacarpal index were calculated on three separate occasions and the mean results utilised.

The height of each child was recorded by the resident nutritionist and is presented as a percentage of the height expected for the child's age according to the Tanner \& Whitehouse standards (20).

\section{RESULTS}

The means of bone age delay, metacarpal index and height for each group are presented in Table 2.

\section{Malnourished children vs}

Comparison children (analysis of variance, randomized block design)

This analysis shows that height is significantly shorter in the previously malnourished ildren $(F=15.5 ; \mathrm{df}=1.51 ; p<0.01)$. Bone age delay and metacarpal index are not signifi-

Table 3. Correlations of 'acute malnutrition' and 'chronic undernutrition' with bone age delay, metacarpal index and height (malnourished groups pooled, $N=3 \times 18$ )

\begin{tabular}{lcc}
\hline & $\begin{array}{l}\text { 'Acute } \\
\text { malnutrition' }\end{array}$ & $\begin{array}{l}\text { 'Chronic } \\
\text { under- } \\
\text { nutrition' }\end{array}$ \\
\hline Bone age lag & -0.19 & 0.09 \\
Metacarpal index & -0.19 & 0.03 \\
Height (\% for age) & 0.12 & $-0.28^{a}$ \\
\hline
\end{tabular}

${ }^{a} p<0.05$, one-tailed test.

\section{'Acute malnutrition' and 'Chronic undernutrition'}

As described above the malnourished children had been scored for the severity of these two components of malnutrition during their admission. Of the two, the first shows no significant correlations with the three dependent variables (Table 3).

'Chronic undernutrition' correlates negatively with present height, while the correlations with bone age delay and metacarpal index are small. This agrees with the previous results and confirms that in the long run only height is significantly affected as distinct from bone age delay and metacarpal index.

'Catch up' between

12 and 16 years of age

The correlation of present age with height (percentage for age) is $\mathbf{0 . 0 2}$ among the malnourished children. If these children were catching up through prolonged growth their height (per cent for age) would improve with age and a positive correlation between the two would therefore be expected. This is clearly not the case and indicates not only that height is permanently affected but also that no "catch up' has occurred in this age group.

Similarly present age and bone age delay correlate -0.02 among the malnourished children indicating that no compensation of previous arrears occurs. Table 4 shows this in a different form by presenting the results for two different age groups. 
Table 4. Means of bone age delay, metacarpal index and height for two groups of malnourished children of different age

\begin{tabular}{|c|c|c|c|}
\hline & \multicolumn{2}{|c|}{$\begin{array}{l}\text { Malnourished children, } \\
\text { present age between }\end{array}$} & \multirow{2}{*}{$\begin{array}{l}\text { Com- } \\
\text { parison } \\
\text { group }\end{array}$} \\
\hline & $\begin{array}{l}11.7-13.6 \\
\text { yrs }\end{array}$ & $\begin{array}{l}13.8-16.8 \\
y r s\end{array}$ & \\
\hline Number of children & $N=26$ & $N=28$ & $N=18$ \\
\hline $\begin{array}{l}\text { Present age, } \\
\text { mean (yrs) }\end{array}$ & 12.9 & 15.0 & 13.8 \\
\hline $\begin{array}{l}\text { Bone age lag, } \\
\text { mean (yrs) }\end{array}$ & 0.73 & 0.66 & 0.22 \\
\hline Metacarpal index & 47.6 & 48.1 & 48.2 \\
\hline Height ( $\%$ for age) & 91.4 & 91.7 & 95.5 \\
\hline
\end{tabular}

No differences appear between the youngest and the eldest age group.

Sex, boys vs girls

A breakdown of the results for boys and for girls is presented in Table 5. Although bone age appears slightly more delayed among boys than among girls this applies to the comparison children as well. The minor tendency of a relatively greater delay in bone age to occur with malnutrition among boys is not corroborated by the height findings which are virtually identical for boys and girls. The small differences in the metacarpal index appear erratic. The analysis of variance in the previous sections 1 and 2 also revealed no significant interaction effects for sex on any of the three dependent variables.

\section{DISCUSSION}

The results obtained from this study indicate that protein energy malnutrition in infancy affects height but has no demonstrable, longterm effect on bone age or metacarpal index when measured 9-15 years later. The height deficit is related to the severity of 'chronic undernutrition' in infancy, but is not related to the severity of 'acute malnutrition' nor to the age period during which the acute attack requiring hospitalisation occurred. There are no indications that any 'catch up' in bone growth occurs between 12 and 16 years of age. The height findings parallel the differences found between heights and weights of children from poor resource countries and children from developed countries. Habicht et al. (9) have emphasized that these differences are largely due to environmental constraints on growth and development and not to ethnic factors.

The present study finds not only that bone age and cortical thickness are not significantly affected by malnutrition at ages 12 to 16 , but also that this applies equally to children who suffered an episode of 'acute malnutrition' at different ages. No indications are found that any compensation has occurred within th present age group. Many of the children in the previously malnourished group had a bone age assessment recorded at the time of admission. Unfortunately only a few of these records could be found; they all indicated definite retardation of bone age. Assuming that bone age was retarded in early childhood one of two conclusions can be drawn. The early retardation as a result of protein energy malnutrition was either too small to be still significant at later ages, or a 'catch up' has occurred before 12 years of age.

These findings are in agreement with the 'catch up' of bone age and metacarpal index found by Barr et al. (3) in treated coeliac disease. They seem, however, at variance with previous studies from East Africa. Mackarrag (13) in a group of normal East Africar. children, demonstrated a bone age delay of $1 \frac{1}{2}$ to 2 years compared with the American

Table 5. Means of bone age delay, metacarpal index and height for boys and girls

\begin{tabular}{|c|c|c|c|c|}
\hline & \multicolumn{2}{|c|}{$\begin{array}{l}\text { Malnourished } \\
\text { children }\end{array}$} & \multicolumn{2}{|c|}{$\begin{array}{l}\text { Comparison } \\
\text { group }\end{array}$} \\
\hline & boys & girls & boys & girls \\
\hline Number of children & $N=30$ & $N=24$ & $N=10$ & $N=8$ \\
\hline $\begin{array}{l}\text { Lag in bone age, } \\
\text { mean (yrs) } \\
\text { Metacarpal index } \\
\text { Height (\% for age) }\end{array}$ & $\begin{array}{r}1.01 \\
46.10 \\
91.30\end{array}$ & $\begin{array}{r}0.30 \\
50.00 \\
91.80\end{array}$ & $\begin{array}{r}0.40 \\
43.60 \\
95.50\end{array}$ & $\begin{array}{r}-0.03 \\
53.90 \\
95.40\end{array}$ \\
\hline
\end{tabular}


standards. In Kampala, Krueger (11) assessed a group of children who had been malnourished 6-11 years previously and compared their bone age with that of a group of American children who form the basis of the standard atlas of Greulich \& Pyle (8). She reported that "bone ages were one or two years below those to be expected from the children's chronological age", but drew no further conclusions from this observation.

Since her work, however, studies have been published showing variation in bone age between the American standards of Greulich \& Pyle and other groups of children from Swe(2) (1), Melbourne (17), Hong Kong (5) and Dakar (15). These variations may reflect differences in developmental maturity, but also result from different methods of assessment. This has been clearly demonstrated by Fry (6) who applied the Tanner \& Whitehouse method of assessment of bone age to the plates in the Greulich \& Pyle atlas and found a mean overall advance in the Tanner \& Whitehouse estimation of over 16 months with a range between -4.1 and +40.4 months. This may explain why in the present study, which used the Tanner \& Whitehouse method, the delay of the malnourished children was only 0.7 year with the standards, while Krueger \& Mackay, using the Greulich \& Pyle standards, reported an age delay of $1 \frac{1}{2}$ to 2 years.

Krueger's observations are difficult to relate to the presence of malnutrition in the absence of a comparison group of Ugandan children who had not suffered from protein energy malnutrition. This is also the case with the study of cortical thickness by Blanco et al. (4). Their conclusion that the difference in mean bone cortical measurements between Guatemalan and American children was the result of malnutrition may be true. The effect of malnutrition on the cortical index could be better assessed by comparison within a single defined population with a documented history of nutritional status, rather than by comparison of different populations.

The current findings appear to parallel those of the comprehensive study by Keet et al. (10) of 123 children who had suffered from kwashiorkor and were subsequently followed for 10 years. These authors used the Greulich \& Pyle standards and found no differences in bone age between the previous malnourished children and their siblings. Neither, however, did the two groups of children differ in height throughout the 10-year study. This may well indicate that although the siblings differed in not having experienced an acute episode of protein energy malnutrition, both groups may have suffered similar degrees of 'chronic undernutrition'. The present study, however, demonstrates that although height has been affected by 'chronic undernutrition' in early childhood, no significant ultimate differences in bone age and bone cortical thickness are present.

Keet et al. and Blanco et al. report that, independent of malnutrition, boys lag further behind American standards in bone age and cortical thickness than girls. This study finds a similar, though minor, trend for bone age but not for cortical thickness and height.

\section{ACKNOWLEDGEMENTS}

The authors wish to thank Dr R G Whitehead and the Medical Research Council for providing the facilities for this study, and to acknowledge the help of the staff of the MRC Child Nutrition Unit and the X-ray Department of Mulago Hospital, Kampala, Uganda.

\section{REFERENCES}

1. Anderson, E.: Comparison of Tanner-Whitehouse and Greulich-Pyle methods in a large Swedish survey. Am J Phys Anthropol, 35: 373, 1971.

2. Barnett, E. \& Nordin, B. E. C.: The radiological diagnosis of osteoporosis: a new approach. Clin Radiol, ll: 166, 1960.

3. Barr, D. G. D., Schmerling, D. H. \& Prader, A Catch up growth in malnutrition, studied in coeliac disease after institution of gluten free diet. Paediatr Res, 6: 521, 1972.

4. Blanco, R. A., Acheson, R. M., Canosa, C. \& Solomon, J. B.: Sex differences in retardation of skeletal development in rural Guatemala. Pediatrics, 50:912. 1972.

5. Fry, E. I.: Tanner-Whitehouse and Greulich-Pyle Skeletal Age Velocity Comparisons. Am J Phys Anthropol, 35: 377, 1971. 
6. Fry, E. I.: Assessing skeletal maturity: comparison of the Atlas and Individual Bone techniques. Nature, 220: 496, 1968.

7. Garrow, J. S. \& Pike, M. C.: The long-term prognosis of severe infantile malnutrition. Lancet, I: 1, 1967.

8. Greulich, W. W. \& Pyle, S. I.: Radiographic Atlas of Skeletal Development of the Hand and Wrist. Oxford University Press, London 1959.

9. Habicht, J.-P., Martorell, R., Yarbrough, C., Malina, R. M. \& Klein, R. E.: Height and weight standards for pre-school children: how relevant are ethnic differences in growth potential. Lancet, I: 611, 1974.

10. Keet, M. P., Moodie, A. D., Wittmann, W. \& Hansen, J. D. L.: Kwashiorkor: a prospective ten year follow up study. S Afr Med J, 85: 1427, 1971.

11. Krueger, R. H.: Some long term effects of severe malnutrition in early life. Lancet, $I I: 514,1969$.

12. McCance, R. A. \& Widdowson, E. M.: Nutrition and growth. Proc R Soc (Series B) 156:326, 1962.

13. Mackay, D. H.: Skeletal maturation in the hand: a study of development in East African children. Trans R Soc Trop Med, 46: 135, 1952.

14. MacWilliam, K. M. \& Dean, R. F. A.: The growth of malnourished children after hospital treatment. East Afr Med J, 42:297, 1965.

15. Michaut-Barthod, E.: Determination de la maturation osseuse de 227 adolescent Dakarios. Thesis, Un1versité de Paris 1971.

16. Prader, A., Tanner, J. M. \& von Harnack, G. A. Catch up growth following illness or starvation. $J$ Pediatr, 62: 646, 1963.

17. Roche, A. F., Davila, G. H. \& Eyman, B. S.: A comparison between Greulich-Pyle and TannerWhitehouse Assessments of Skeletal Maturity Radiology, 98: 273, 1971.

18. Stuart, H. S. \& Stevenson, S. S. In W. E. Nelson (ed.) Textbook of Pediatrics. Saunders, Philadelphia 1964, p. 48.

19. Tanner, J. M. \& Whitehouse, R. H.: Standards for skeletal age. International Children's Centre, 1959

20. Tanner, J. M., Whitehouse, R. H. \& Takaishi, M.. Standards from birth to maturity for height, weight, height velocity and weight velocity; British children, 1965. Arch Dis Child, 4l: 454, 1966.

Submitted Jan. 29, 1975

Accepted May 21, 1975

(J. P. S.) Social Paediatric and Obstetric Research Unıt 23 Montrose Street

Glasgow, GIRN

Scotland 